\title{
Analysis and Improvement of the Thermal Behavior of Social Houses in Northern Argentina Through Transient Thermal Simulation
}

\author{
S. Flores Larsen ${ }^{1} *$, C. Filippín ${ }^{2}$ and L. Flores \\ ${ }^{I}$ INENCO-Non Conventional Energies Research Institute, National University of Salta, CONICET, Argentina and \\ ${ }^{2}$ CONICET - CC302, Santa Rosa, 6300 (La Pampa) Argentina
}

\begin{abstract}
The analysis of the winter and summer thermal behavior of a low-income dwelling, built by Provincial Institute of Dwelling in Salta, is presented. For both orientations of the major axis, the mean indoor temperatures in winter were around $14^{\circ} \mathrm{C}$ with a daily thermal swing between $5^{\circ} \mathrm{C}$ and $10^{\circ} \mathrm{C}$, values that are outside the comfort area. Thus, auxiliary conventional heating is needed during all the day. In summer, the dwellings are almost all the day outside the comfort area, with indoor temperatures higher than outdoor air and thermal swings between $7^{\circ} \mathrm{C}$ and $10^{\circ} \mathrm{C}$. Clearly there is a lack of storage mass to moderate the internal air swing. A set of alternatives to improve the indoor thermal comfort was analyzed. The program SIMEDIF for Windows was used to simulate the hourly thermal behavior of the dwelling.
\end{abstract}

\section{INTRODUCTION}

The actual energy situation in the World, the lower levels of available fossil fuel, and the damage produced to the environment by the use of conventional energy, increases the search for mid and long-time solutions to lower the conventional energy consumption and the emission of greenhouse gases. It is well known that around $30 \%$ of the global energy consumption in the world corresponds to the building sector (heating, cooling, and lighting). In Argentina the unusual meteorological conditions, local economic and politic factors and international compromises caused a serious energy crisis during 2007, when the historic national demand of energy was exceeded several times during the winter. There were interruptions in the gas and electricity supply to the industries to ensure the energy supply to the inhabitants. This situation caused a lowering in the growth of the industrial production from $6.4 \%$ in the first months of the year down to $2.7 \%$, as pointed out in the reports of the National Institute of Statistics and Censuses of Argentina (INDEC 2007) [1]. The cumulative growth of the energy demand of the overall country, as reported by the Electric Energy Deliverers Association of the Argentinean Republic (ADEERA), increased up to $6.71 \%$ in the first seven months of the year. The situation is not much better in summer, due to the increase in the sales of HVAC equipments in the last two years in Argentina: the demand of HVAC systems grew up to $95 \%$ in may 2007 , compared with the previous month. The search of concrete solutions to the energetic problem is a fundamental issue at national level that includes two aspects: the installation of new plants for energy generation and the reduction of the energy consumption through adequate saving strategies.

In the design and construction of social houses by national and provincial governmental planes, the projects

*Address correspondence to this author at the INENCO-Non Conventional Energies Research Institute, National University of Salta, CONICET, Argentina; E-mail: mailto:seflores@unsa.edu.ar commonly trends to reduce the economic costs without any care about the consequences in the thermal comfort, the life quality, and the extra energy consumption required to compensate the design errors and the poor quality of the building materials. In general the designs are completely unadapted to the climatic conditions of the site and it is very frequent the use of the same house design in sites with completely different climates. The socio-economic level and the low incomes of the inhabitants do not allow the acquisition of heating and/or cooling systems to improve the indoor conditions, so the houses are completely out of the comfort zone in the most rigorous periods. This is also true in summer, when the owners support a forced adaptation to the hot indoor environment. In Argentina some effort was made to detect this kind of problems through the evaluation of the thermal behaviour of these dwellings and the search of alternative solutions [2-4], but they are isolated efforts of researchers at the universities and some people in the construction environment who tried to change this situation and whose efforts are becoming clear since the last years [5-7]. Local building designers have largely ignored passive design strategies that could allow building passive social houses with very low energy use and to normal costs $[8,9]$. One reason is that local laws are not yet seriously compromised with lowering energy consumption of buildings and there are no restrictions on how much energy a building should consume.

An indispensable tool for the design of an energy efficient building is the simulation of its thermal behaviour under the site meteorological conditions. The use of such programs allows improving the building design to reduce the conventional energy consumption. A previous simulation stage is crucial to predict the winter and summer thermal behaviour of the building, helping to choose among different materials and technology for the building envelope, glazed areas, shape, orientation, and so on. Thus, a feedback is carried out until an adequate final project is achieved [10]. The study of building thermal performance through transient simulation is 
crucial to face real world problems in the design of energy efficient buildings.

In Argentina, a lot of effort was directed since 1984 to develop a code for the simulation of transient thermal behaviour of passive multi-room buildings. The result is SIMEDIF, a program made by researchers of INENCO (Non Conventional Energy Research Institute), with a first version developed for DOS by Casermeiro and Saravia [11] in 1984. Since then the code was improved and validated throughout years of experimental work in Argentina. Numerous groups continuously used it for research [12], design, and simulation of the thermal behaviour of lightweight $[13,14]$ and massive [15] buildings under very different climatic conditions. Since 2000 the code has being updated with new features and adapted for Windows environment [16]. The access and downloading is completely free from the Internet. Because this software is used in this paper, a brief description of its thermal model is included. The general aim of this paper is the study of the hourly thermal behaviour, for winter and summer, of a social dwelling in Salta city, at the northwest of Argentina, built by the Provincial Dwelling Institute. The heating energy consumption in winter is analyzed and a variety of technological solutions are studied.

\section{DWELLING DESCRIPTION}

The houses were built in Salta (24 03' South latitude, $65^{\circ} 44^{\prime}$ 'Western longitude, $1187 \mathrm{~m}$ over the sea level), in the western sector of the city, in a zone with disperse constructions and high exposition to winds. The climate is defined as subtropical with a dry season, corresponding to the bioenvironmental zone IIIa (Norma IRAM 11603 1993) [17]. Table 1 shows the climatic data of the region, provided by the National Meteorological Service.

The dwellings were designed in a peered typology, as shown in Fig. (1) (House 1 to the left; House 2 to the right), and they were oriented by following the access streets. Two representative orientations were studied: with the major axis in the East-West direction and in the North-South direction. Each dwelling has two bedrooms, a bathroom, a kitchen and a living room. The covered area of each house is $44 \mathrm{~m}^{2}$. The vertical envelope is made of $0.18 \mathrm{~m}$ thick hollow ceramic brick, plastered in both sides, without thermal insulation. The interior partitions are made of hollow ceramic bricks of $0.08 \mathrm{~m}$ thick and 0.12 thick, with plaster on both sides. The horizontal envelope is a $0.2 \mathrm{~m}$ thick lightweight slab made of concrete beams and hollow ceramic bricks, a $3 \mathrm{~mm}$ waterproof membrane, a $0.01 \mathrm{~m}$ sheet of expanded polystyrene as thermal insulation, and semicircular colonial roof tiles supported by a $0.025 \mathrm{~m}$ thick concrete layer. The glazed area is around a $15 \%$ of the floor area. The window frames are metallic with medium air tightness and the doors are made pine wood.

\section{METHODOLOGY}

\section{Breaf Description of SIMEDIF}

The houses were simulated with SIMEDIF for Windows [18]. SIMEDIF needs the building to be divided into thermal zones. A zone is a building space that can be considered isothermal. It is characterized by its air volume and the air changes per hour. Each zone is represented by an air node with a single temperature, whose temporal evolution is determined by using the building data, materials, location, orientation, connections with other zones and exterior meteorological conditions. The zones can be connected to each other and with the exterior environment by the following predefined elements:

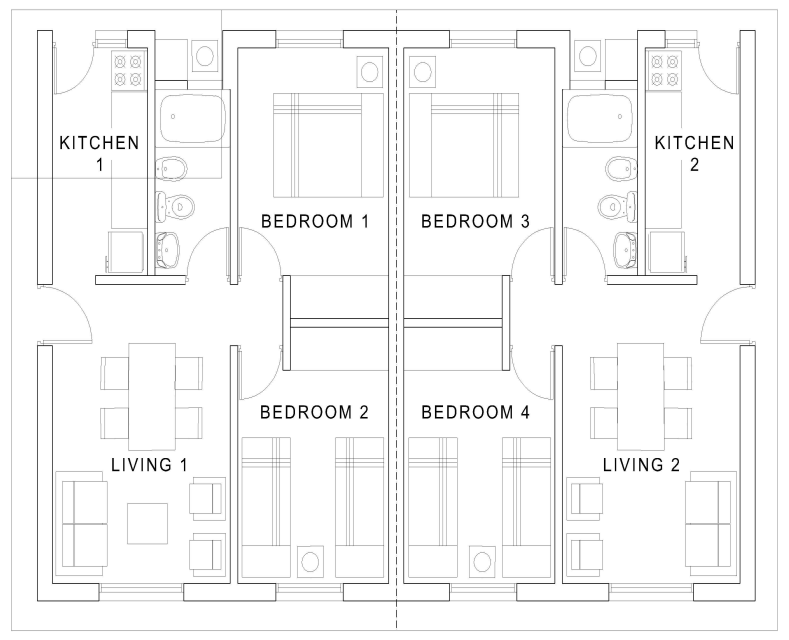

Fig. (1). Scheme of peered houses. At left House 1 (Kitchen 1, Living 1, Bedroom 1, Bedroom 2); at right House 2 (Kitchen 2, Living 2, Bedroom 3, Bedroom 4).

Massive walls, that storage and transfer heat by conduction. There is a temperature profile inside the wall. They can include layers of different materials.

Water walls, that storage heat in a liquid where a homogeneous temperature is maintained through convection inside the liquid mass.

Partitions, that transmit the heat by conduction, without store it.

Glazed areas, that transmit the heat by conduction, with two heat transfer coefficients (day and night), such as windows with night insulation. The ventilation and direct solar gain are treated separately, as shown later.

Openings, that includes air mass exchanges. The heat is transferred by natural convection, as in opened doors and vents.

An energy balance is performed at each node for which the temperature is to be determined. These nodes are of two different types: massive nodes (i.e., the nodes on massive walls and water walls) and non-massive nodes (i.e., the nodes on air and surfaces of partitions). Some hypotheses are used:

The heat transfer through massive walls is one dimensional. The walls can be made of different materials (characterized by their conductivity, density, and specific heat to constant pressure).

The heat transfer between a building surface and the surrounding air is described with a global time-invariant heat transfer coefficient $h\left(\mathrm{~W} / \mathrm{m}^{2} \mathrm{~K}\right)$, which includes convection and radiation.

The building surfaces are described by an absorption coefficient, and they can receive solar radiation on its entire 
surface or on a smaller area AR. In the calculation, the radiation is spread on the overall surface.

The air renewals can be different in each thermal zone, with a constant value during the simulation period.

Table 1. Climatic Conditions For Salta, At $2^{\circ}$ 03' South Latitude, 65'44' Western Longitude, 1187 M Over The Sea Level

\begin{tabular}{|c|c|c|}
\hline \multirow{8}{*}{ 妾 } & \multicolumn{2}{|l|}{ TEMPERATURE $\left({ }^{\circ} \mathrm{C}\right)$} \\
\hline & Mean minimum & 11.2 \\
\hline & Mean & 16.9 \\
\hline & Mean maximum & 24 \\
\hline & Heating Degree Day (Base temperature $22^{\circ} \mathrm{C}$ ) & 1703 \\
\hline & Cooling Degree Day (Base temperature $23^{\circ} \mathrm{C}$ ) & 347 \\
\hline & \multicolumn{2}{|l|}{ RELATIVE HUMIDITY (\%) } \\
\hline & Mean & 71 \\
\hline \multirow{7}{*}{ 岳 } & \multicolumn{2}{|l|}{ TEMPERATURE $\left({ }^{\circ} \mathrm{C}\right)$} \\
\hline & Mean minimum & 4 \\
\hline & Mean & 10.4 \\
\hline & Mean maximum & 17.6 \\
\hline & \multicolumn{2}{|c|}{ DAILY MEAN IRRADIANCE (MJ/m²) } \\
\hline & On horizontal surface & 13 \\
\hline & MEAN WIND VELOCITY (km/h) & $5 \mathrm{~km} / \mathrm{h}$ \\
\hline \multirow{7}{*}{ 空 } & \multicolumn{2}{|l|}{ TEMPERATURE $\left({ }^{\circ} \mathrm{C}\right)$} \\
\hline & Mean minimum & 17 \\
\hline & Mean & 21.3 \\
\hline & Mean maximum & 28.2 \\
\hline & \multicolumn{2}{|c|}{ DAILY MEAN IRRADIANCE (MJ/m²) } \\
\hline & On horizontal surface & 22 \\
\hline & MEAN WIND VELOCITY (m/s) & $4 \mathrm{~km} / \mathrm{h}$ \\
\hline
\end{tabular}

An initial temperature value is needed for massive nodes.

SIMEDIF calculates the temperatures $T_{i}(t)$ inside and on the surfaces of all massive walls. Each wall is divided into a number of layers defined by the user, and the heat transfer equation in one-dimension is applied to each layer. This set of equations constitutes an initial value problem. Initial conditions, consisting of the starting storage mass temperatures and air temperatures, must be specified. The finite-difference explicit method is used to replace the time and spatial derivatives by finite differences and the result is a set of equations for all the massive nodes. The temperature at time $t+\Delta t$ can be evaluated from temperatures at the previous time $t$.

The room drybulb temperature $T_{r}(t)$ at $t+\Delta t$ is computed from the global heat balance equation valued in the previous instant $t$. In this global balance equation, the air renewals in the room, inner heat gains, and heat transfer due to the different elements connecting the room with other zones in the building and with outdoors, are considered. A detailed expression for this balance equation can be found in [16].

\section{Thermal Simulations of the Houses for Winter And Summer}

Two periods of ten days each one were simulated, for June (winter) and for January (summer). The meteorological data were obtained from Table 1. Because of the typology, the two dwellings were simulated simultaneously. Each dwelling has four thermal zones: Kitchen (this zone includes the bathroom), two Bedrooms and a Living. The names, location, air volume, air changes per hour, glazed area, and floor area of the thermal zones are presented in Table $\mathbf{2}$. The air changes in winter are due exclusively to the air infiltrations, and they were estimated by considering a metallic carpentry commonly used in the construction, with a medium infiltration rate. The air changes in summer were estimated by considering a mean wind velocity and a discharge coefficient around 0.7, as proposed by Balcomb [19]. The thermal properties of the construction materials were obtained from the available heat transfer literature.

Table 2. Names, Location, and Characteristics of the Thermal Zones

\begin{tabular}{|c|c|c|c|c|}
\hline \multirow{4}{*}{ House } & Name & $\begin{array}{c}\text { Floor } \\
\text { Area }\left(\mathbf{m}^{2}\right)\end{array}$ & Volume $\left(\mathbf{m}^{3}\right)$ & $\begin{array}{c}\text { Glazed } \\
\text { Area }\left(\mathbf{m}^{2}\right)\end{array}$ \\
\hline \hline \multirow{4}{*}{ House 1 } & Kitchen 1 & 7.9 & 24 & 0.7 \\
\cline { 2 - 5 } & Bedroom 1 & 9.4 & 29 & 1.3 \\
\cline { 2 - 5 } & Bedroom 2 & 8.6 & 27 & 1.3 \\
\cline { 2 - 5 } & Living 1 & 11.3 & 35 & 2.6 \\
\hline \multirow{3}{*}{ House 2 } & Kitchen 2 & 7.9 & 24 & 0.7 \\
\cline { 2 - 5 } & Bedroom & 9.4 & 29 & 1.3 \\
\cline { 2 - 5 } & Bedroom 4 & 8.6 & 27 & 1.3 \\
\cline { 2 - 5 } & Living 2 & 11.3 & 35 & 2.6 \\
\hline \multirow{2}{*}{ Total } & & 74.4 & 230 & 11.8 \\
\hline
\end{tabular}

The interior partitions of ceramic brick were simulated through a Conductance Coefficient $C=2.14 \mathrm{~W} / \mathrm{m}^{2}{ }^{\circ} \mathrm{C}$. The windows were simulated with two coefficients to include the use of the wood shutters during the night: values of 5.8 $\mathrm{W} / \mathrm{m}^{2} \mathrm{~K}$ (day) and $2.8 \mathrm{~W} / \mathrm{m}^{2} \mathrm{~K}$ (night) were used. The interior convective-radiative heat transfer coefficients were estimated from empirical correlations [20]: 8 and $6 \mathrm{~W} / \mathrm{m}^{2} \mathrm{~K}$ (for surfaces receiving or not direct solar radiation, respectively). The convective-radiative coefficients for external surfaces were estimated through the dimensional equation [21]:

$\mathrm{h}=5.7+3.8 \mathrm{y}$

where $h$ is the convective-radiative heat transfer coefficient in $\mathrm{W} / \mathrm{m}^{2} \mathrm{~K}$ and $v$ is the mean wind velocity in $\mathrm{m} / \mathrm{s}$. The mean 
wind velocities were obtained from the meteorological data (Table 1).

Because the house's orientation depends on the mapping of the actual streets, the simulations were carried out for two different situations: the major axis in the East-West direction and in the North-South direction.

\section{RESULTS}

\section{Thermal Behavior of the Original Design}

Figs. (2) to (5) show the hourly thermal behavior of the thermal zones in each house for these two orientations, in winter and in summer.

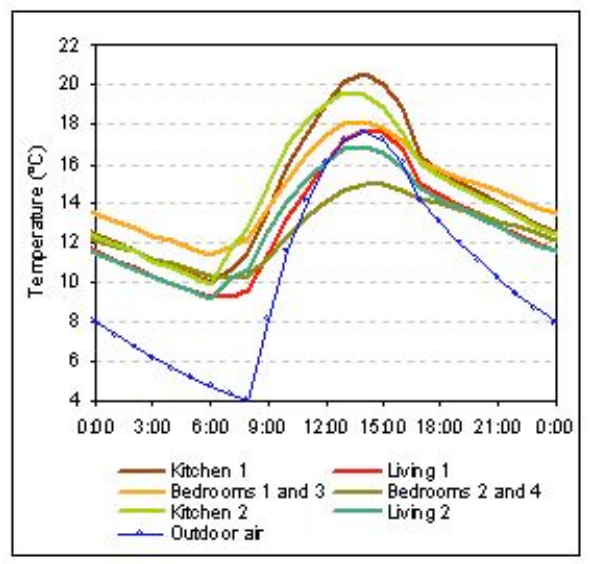

Fig. (2). Hourly thermal behavior of the zones in each house for a typical winter period, with the major axis in the East-West direction.

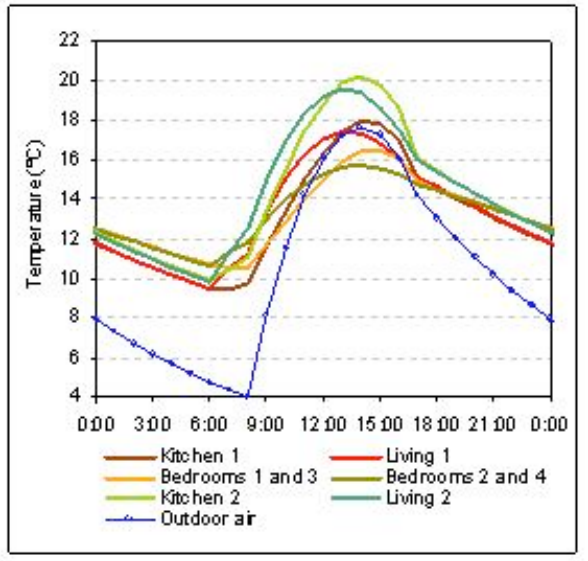

Fig. (3). Hourly thermal behavior of the zones in each house for a typical winter period, with the major axis in the North-South direction.

During the sunny hours in winter (Figs. 2 and $\mathbf{3}$ ) and with exterior air temperatures around $17.6^{\circ} \mathrm{C}$, the North oriented zones reach temperatures higher than the outside air and thermal amplitudes higher than the South oriented zones. As an example, for the houses with their major axis in the EastWest direction, the warmest zones are the Kitchens (1 and 2, with maximum temperatures around $20^{\circ} \mathrm{C}$ ) and the Bedrooms 1 and 3 (with maxima around $18^{\circ} \mathrm{C}$ ). The South oriented zones, even at noon, do not overcome the outside air temperature (Bedrooms 2 and 4 reach $15^{\circ} \mathrm{C}$ only at noon).
Because Living 1 has a Western wall, its thermal behavior is the best of the South oriented zones, with a maximum temperature around $18^{\circ} \mathrm{C}$. For the houses with their major axis in the North-South direction, the warmest zones are the Kitchens and Livings (maximum temperatures of $19^{\circ} \mathrm{C}$ and $20^{\circ} \mathrm{C}$, respectively), and the coldest one are the Bedrooms, with low direct solar gains and maximum temperatures around $16^{\circ} \mathrm{C}$. In this orientation, the House 1 with a mean temperature of $13.3^{\circ} \mathrm{C}$ is colder than House 2, with $14^{\circ} \mathrm{C}$.

Without regard the axis orientation, some significant conclusions are a) the mean temperatures of the houses' zones are outside the comfort zone (between $13.3^{\circ} \mathrm{C}$ and $14^{\circ} \mathrm{C}$ ), b) the indoor thermal swings (between $5^{\circ} \mathrm{C}$ and $10^{\circ} \mathrm{C}$ ) are higher than the recommended limit; and c) auxiliary heating will be necessary during the whole day to reach the thermal comfort. It is very important to note that, for this climate, the use of thermal insulation in the external walls will reduce the heat losses to the outside environment but it will not increment the indoor mean temperature or reduce the thermal swing. The simulations of the walls with the addition of a thermally insulating layer indicates that the auxiliary energy consumption for space heating is reduced, but not in a highly significant amount (around 10\%). Thus, the compromise between the energy savings and the cost of the thermal insulation must be evaluated.

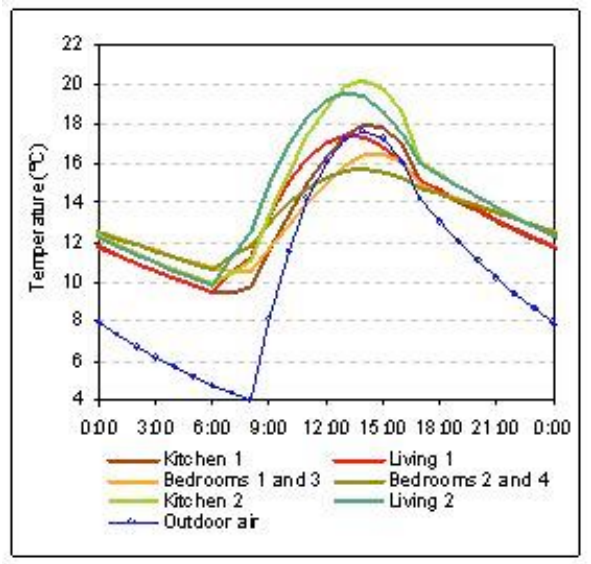

Fig. (4). Hourly thermal behavior of the zones in each house for a typical winter period, with the major axis in the East-West direction.

In summer (Figs. 4 and 5) the exterior air temperature for a typical day oscillates between $17^{\circ} \mathrm{C}$ and $28^{\circ} \mathrm{C}$. In the last five years these typical days were unusual, and maximum temperatures reaching $40^{\circ} \mathrm{C}$ were common. It is observed that indoor temperatures are zonified in relation with the wall areas exposed to the outdoor environment: the four Bedrooms, with lowest exposed areas, are warmer than the Livings and Kitchens, with temperatures around $30^{\circ} \mathrm{C}$. The thermal swings are between 7 and $10^{\circ} \mathrm{C}$. Again the houses are outside the thermal comfort zone. As explained earlier, the low incomes of the inhabitants of these social houses make them hard to acquire HVAC systems. Thus, it is fundamental to improve the hygrothermal indoor conditions of the houses also in summer. The general recommendations of natural ventilation, the inclusion of thermal insulation in the West walls, and the minimization of the direct solar heat gain by means of shading devices, window shutters and de- 
ciduous vegetation, are not sufficient to ensure the indoor thermal comfort. This is because the houses lack of sufficient thermal mass to absorb the indoor heat and to minimize the thermal swings. This lack has been reported in previous papers about social houses in Argentina (Filippín and Flores Larsen) [3] and even in residential houses with an excellent finishing, built with $0.20 \mathrm{~m}$ thick concrete cellular blocks of $125 \mathrm{~kg} / \mathrm{m}^{2}$ [22].

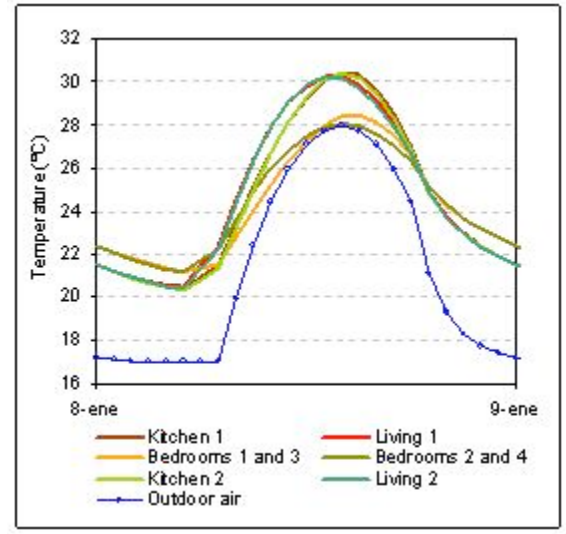

Fig. (5). Hourly thermal behavior of the zones in each house for a typical winter period, with the major axis in the North-South direction.

Table 3 shows the mean temperatures of each house for the two orientations, in winter and summer. If the orientation is analyzed, the indoor temperatures of the houses with their major axis in the East-West direction are lower in summer than the North-South oriented. In winter also the East-West direction is better, because both houses 1 and 2 have similar mean temperatures.

Table 3. Mean Temperatures of Houses 1 And 2, for the Two Axis Directions, in Winter and Summer

\begin{tabular}{|c|c|c|c|}
\hline & & House 1 & House 2 \\
\hline \hline \multirow{2}{*}{} & $\begin{array}{c}\text { Axis in the East-West direc- } \\
\text { tion }\end{array}$ & $13.6^{\circ} \mathrm{C}$ & $13.6^{\circ} \mathrm{C}$ \\
\cline { 2 - 4 } & $\begin{array}{c}\text { Axis in the North-South } \\
\text { direction }\end{array}$ & $13.3^{\circ} \mathrm{C}$ & $14.0^{\circ} \mathrm{C}$ \\
\hline \multirow{2}{*}{$\begin{array}{c}\text { Axis in the East-West direc- } \\
\text { tion }\end{array}$} & $24.2^{\circ} \mathrm{C}$ & $23.5^{\circ} \mathrm{C}$ \\
\cline { 2 - 4 } & $\begin{array}{c}\text { Axis in the North-South } \\
\text { direction }\end{array}$ & $24.6^{\circ} \mathrm{C}$ & $23.6^{\circ} \mathrm{C}$ \\
\hline
\end{tabular}

\section{Thermal Behavior with Different Improved Envelopes}

Possible alternatives to the problem of thermal mass lack were studied:

a) A vertical envelope of $0.3 \mathrm{~m}$ thick massive brick, plastered on both sides.

b) A vertical envelope of $0.3 \mathrm{~m}$ thick massive brick with a $0.03 \mathrm{~m}$ sheet of expanded polystyrene as thermal insulation, plastered on both sides.

Also the effect of the thermal insulation in the roof was studied: c) Original house with a $0.03 \mathrm{~m}$ extra sheet of expanded polystyrene in the roof.

d) Case $a$ with a $0.03 \mathrm{~m}$ extra sheet of expanded polystyrene in the roof.

e) Case $b$ with a $0.03 \mathrm{~m}$ extra sheet of expanded polystyrene in the roof.

Only the East-West orientation was studied in order to simplify the comparison of the simulated results for the alternatives $a$ to $e$. Because the indoor variations between the thermal zones were previously established, in this section the different zones of both houses were averaged hour by hour to obtain a single result for each hour. The results for the five alternatives are shown in Figs. (6) and (7), for typical summer and winter days. The previously discussed configuration of ceramic brick walls with thermal insulation was also included, and it can be verified that the inclusion of thermal insulation to this type of walls does not reduce significantly the indoor thermal swing nor in winter nor summer.

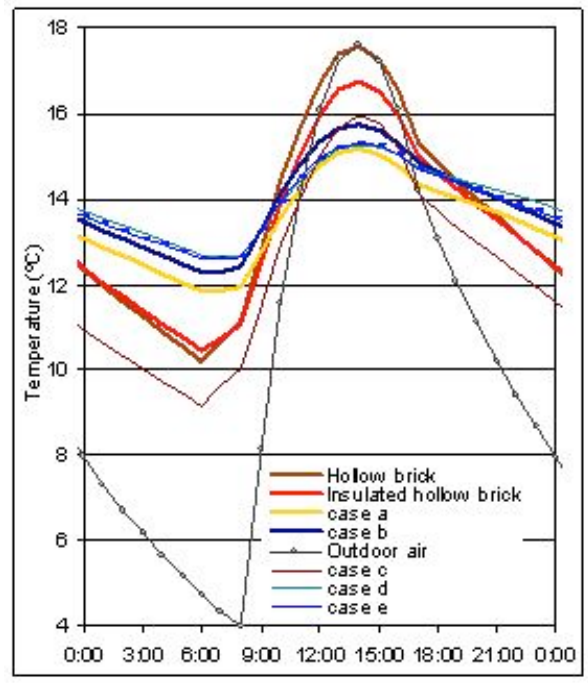

Fig. (6). Hourly mean temperature of the houses in a winter day, for different envelopes alternatives.

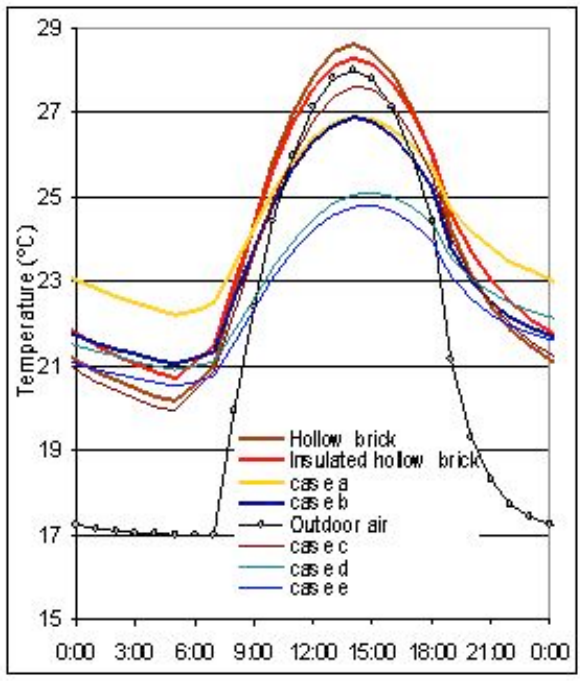

Fig. (7). Hourly mean temperature of the houses in a summer for different envelopes alternatives. 
In winter the daily mean indoor temperatures obtained in all the alternatives are similar, between $13.5^{\circ} \mathrm{C}$ and $14^{\circ} \mathrm{C}$. The difference between them is the thermal swing: for the ceramic hollow brick walls (with or without thermal insulation) the thermal swings are $7^{\circ} \mathrm{C}$ or more, with or without thermal insulation in the roof. For the massive brick wall (case $a$ ), the thermal swing is reduced down to $3.5^{\circ} \mathrm{C}$. If thermal insulation is added to the massive brick wall (case $b$ ), the mean indoor temperature increases $0.5^{\circ} \mathrm{C}$. For the massive brick wall, with or without thermal insulation, the effect of an extra thermal insulation in the roof also causes a decrement of the thermal swing, down to $2.8^{\circ} \mathrm{C}$ (cases $d$ and $e$ ). The area of roof $\left(44 \mathrm{~m}^{2}\right)$ is quite similar to the area of external walls $\left(40 \mathrm{~m}^{2}\right)$, so the cost of insulate the roof is roughly the same that to insulate the walls. Thus, if a choose of one or other must be made it is preferable firstly the addition of insulation in the roof, due to the thermal benefits obtained for the summer period.

There is a similar situation in summer: for the ceramic hollow brick walls the indoor thermal swing is always higher than $7^{\circ} \mathrm{C}$ and the indoor temperatures are higher than outdoors during the whole day. This behaviour remains the same if using or not thermal insulation in walls and/or roof. When the envelope is made of massive brick, the indoor temperatures are lower than outdoor temperatures around noon, and the thermal swing is reduced from $8.5^{\circ} \mathrm{C}$ (hollow ceramic brick) to $4.5^{\circ} \mathrm{C}$ (massive brick). In summer the inclusion of thermal insulation in the roof is very significant when the walls are massive, and the indoor air temperature can be lowered $3^{\circ} \mathrm{C}$ down during the sunny hours when the roof has an extra insulation sheet. In this case, again it is preferable to firstly add insulation in the roof and then, if possible, in the walls. During the night, the outdoor air temperature is quite low to recommend nocturnal ventilation in order to cool the storage mass.

Table 4. Economic Costs of the Vertical and Horizontal Envelope, Including Materials and Workmanship (2007 Costs)

\begin{tabular}{|c|c|c|c|}
\hline \multicolumn{2}{|r|}{ Envelope } & $\mathbf{U S} \$ / \mathbf{m}^{2 *}$ & Total Envelope \\
\hline \multirow{3}{*}{ : } & $\begin{array}{l}\text { Hollow ceramic brick plas- } \\
\text { tered on both sides }\end{array}$ & 22 & 894 \\
\hline & $\begin{array}{l}\text { Massive brick plastered on } \\
\text { both sides }\end{array}$ & 30 & 1206 \\
\hline & $\begin{array}{l}\text { Massive brick with thermal } \\
\text { insulation, plastered on both } \\
\text { sides }\end{array}$ & 34 & 1349 \\
\hline \multirow{2}{*}{ 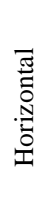 } & $\begin{array}{l}\text { Original roof (lightweight } \\
\text { slab, membrane, } 0.01 \text { mthick } \\
\text { insulation, and colonial tiles) }\end{array}$ & 61 & 2682 \\
\hline & $\begin{array}{l}\text { Original roof with extra } \\
0.03 \mathrm{~m} \text { thick insulation }\end{array}$ & 66 & 2891 \\
\hline
\end{tabular}

Table 4 shows the economic cost per square meter of the envelope (walls and roof) and the total cost per house. The increment of making massive the envelope with respect to the original design is around $35 \%$. The addition of insulation in the walls increments up to $50 \%$ the costs. When the total house envelope cost is considered, the increment does not exceed $5 \%$ and the improvements on the thermal comfort are important. The insulation in the roof increments a $7 \%$ the roof cost.

\section{CONCLUSION}

The analysis of the thermal behaviour of this social house allowed to establish some important conclusions for the original design: without regard the house orientation, in winter the indoor air temperatures are between $13.3^{\circ} \mathrm{C}$ and $14^{\circ} \mathrm{C}$, with thermal swings between $5^{\circ} \mathrm{C}$ and $10^{\circ} \mathrm{C}$. The indoor conditions are outside the comfort area and conventional auxiliary heating is needed during the whole day. The use of thermal insulation in the walls or in the roof lowers the heat losses and reduces the energy consumption for space heating in around $10 \%$, but it does not increment the indoor mean temperature nor temperate the daily thermal swing. In summer the houses are also outside the comfort zone, with indoor air temperatures higher than the exterior environment and thermal swings between 7 and $10^{\circ} \mathrm{C}$. It becomes clear that the main problem is the lack of storage mass to control the indoor thermal swing.

Different economic alternatives were proposed and evaluated for walls and roof. The simulation results for winter indicate that for all the proposed alternatives the obtained indoor temperatures are similar, between $13.5^{\circ} \mathrm{C}$ and $14^{\circ} \mathrm{C}$. The substantial difference is the effect on the daily thermal swing: for hollow ceramic brick walls, with or without thermal insulation, the thermal swings are higher than $7^{\circ} \mathrm{C}$; for $0.3 \mathrm{~m}$ thick massive brick walls the thermal swing is reduced to $3.5^{\circ} \mathrm{C}$. In summer there is a similar situation: with ceramic brick walls the houses have temperatures higher than the exterior air and high thermal swings, while when massive walls are used, the heat during the day is stored in the thermal mass causing the indoor temperature to be lower than the exterior one and an important reduction in the daily thermal amplitude. In summer it becomes important to include thermal insulation in the roof and it is fundamental to practice nocturnal ventilation in order to cool the storage mass.

It must be pointed out that during the last years a great number of houses were built by following the deficient design described in this paper, without any consideration about the thermal comfort. There is no register that such studies were performed for this or other designs of social houses. Besides, socio-environmental factors such as life-styles and behaviour of users, associated to the active energy contribution and preferences of heating levels, have direct incidence on the optimal energy behaviour of buildings and their thermal comfort. It becomes fundamental to educate and involve the users in the correct management of their houses, which is still another challenge.

\section{AKNOWLEDGEMENTS}

This paper was partially financed by CIUNSa $\mathrm{N}^{\circ} 1699$, ANPCYT PAE ex PAV 22559 - BID 1718/OC-AR and ANPCYT PICTO UNSa Nº36646. 


\section{REFERENCES}

[1] INDEC. Institut Nacional de Estadísticas y Censo. Available: http://www.indec.mecon.ar. [Accessed Aug. 2007].

[2] A. Cortés, E. Di Bernardo, J.J. Eliçabe Urriol., P. Mosconi, J. Vázquez, "Climatización estival de viviendas de bajo costo mediante estrategias pasivas", Energías Renovables y Medio Ambiente, vol. 16, pp. 41-46, 2005

[3] C. Filippin, S. Flores Larsen, "Comportamiento térmico de invierno de una vivienda convencional en condiciones reales de uso", Avances en Energías Renovables y Medio Ambiente, vol. 9, pp. 05.67$05.72,2005$.

[4] C. Filippín, S. Flores Larsen, "Comportamiento energético de verano de una vivienda convencional en la región central de argentina", Avances en Energías Renovables y Medio Ambiente, vol. 10, pp. 05.09-05.14, 2006.

[5] G. Lesino, R. Requena, L. Saravia, L. Fontanilla, R. Echazú, "Edificios solares en la puna: estado de avance de su construcción y modelización", in Proceedings of $78^{\mathrm{a}}$ Reunión de la Asociación Argentina de Energía Solar, Rosario (Argentina), pp. 138-145, 1981.

[6] C. de Rosa, M. Basso, A. Esteves, A. Pattini, J. C. Fernández Llano, J. L. Cortegoso, J. Mitchell, M.A.Guisasola, G. Lesino, L. Saravia, "Escuela solar técnico agraria en mendoza. análisis del beneficio invernal de la incorporación de un invernadero adosado", Energías Renovables y Medio Ambiente, vol. 1, pp. 11-19, 1996.

[7] G. Lesino, R. Requena, R. Caso, A. Hernández, N. Salvo, "Vivienda liviana aislada con servicios solares", Energías Renovables y Medio Ambiente, vol. 3, pp. 47-54, 1997.

[8] F. Garde, A. Adelard, H. Boyer, C. Rat, "Implementation and experimental survey of passive design specifications used in new low-cost housing under tropical climates", Energy and Buildings, vol. 36, pp. 353-366, 2004.

[9] M. Macias, A. Mateo, M. Schuler, E.M. Mitre, "Application of night cooling concept to social housing design in dry hot climate", Energy and Buildings, vol. 38, pp. 1104-1110, 2006.

[10] S. Citherlet, J.A. Clarke, J. Hand, "Integration in building physics simulation", Energy and Buildings, vol. 33, pp. 451-461, 2001.
[11] M. Casermeiro, L. Saravia, "Cálculo térmico horario de edificios

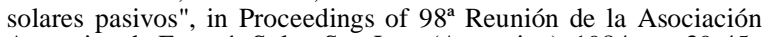
Argentina de Energía Solar, San Juan (Argentina), 1984, pp. 39-45.

[12] A. Esteves, J. Fernández, M. Basso, J. Mitchel, C. de rosa, "simulación térmica de edificios: aplicación de los modelos quick y simedif", in Proceedings of $178^{\circ}$ Reunión de la Asociación Argentina de Energía Solar, Rosario, Argentina, 1994, pp. 543-550.

[13] A. Hernández, G. Lesino, "Análisis de la performance térmica de un prototipo de vivienda liviana: monitoreo y simulación macrodinámica. Parte I", in Proceedings of $168^{\circ}$ Reunión de la Asociación Argentina de Energía Solar, La Plata (Argentina,) 1993, pp. 167174 .

[14] A. Hernández, G. Lesino, "Simulación mediante SIMEDIF del comportamiento térmico de un prototipo de vivienda liviana construido en la universidad nacional de salta", Avances en Energías Renovables y Medio Ambiente, vol. 4, pp. 08.29-08.34, 2000.

[15] S. Flores Larsen, A. Hernández, G. Lesino, N. Salvo, "Measurement and simulation of the thermal behaviour of a massive building with passive solar conditioning", in proceedings of VII international building simulation congress(Brazil), río de janeiro, 2001, pp. 183-190.

[16] S. Flores Larsen, G. Lesino, "A new code for the hour-by-hour thermal behaviour simulation of buildings", in proceedings of VII International Building Simulation Congress(Brazil), Río de Janeiro, 2001, pp. 75-82.

[17] IRAM, Norma 11603: Acondicionamiento térmico de edificios. Clasificación bioambiental de la República Argentina, Buenos Aires, 1996.

[18] S. Flores Larsen, G. Lesino, "Modelo térmico del programa SIMEDIF de simulación de edificios", Energías Renovables y Medio Ambiente, vol. 9, pp. 15-24, 2001.

[19] J. Balcomb, Passive solar buildings. London: MIT Press, 1992

[20] A. Bejan, Heat Transfer, New York: John Wiley and Sons, 1993.

[21] J.A. Duffie, W.A. Beckman, Solar Engineering of Thermal Processes, 2nd ed. New York: Wiley Interscience, 1991.

[22] C. Filippín, S. Flores Larsen, L. Flores, "Comportamiento energético de verano de una vivienda másica y una liviana en la región central de argentina", Avances en Energías Renovables y Medio Ambiente, vol. 11,pp. 05.17-05.23, 2007. 